\title{
Does tourism lead to peace?
}

\author{
Becken, Susanne \& Carmignani, Fabrizio
}

Please cite as:

Becken, S. \& Carmignani, F. (2016). Does tourism lead to Peace? Annals of Tourism Research, 61, 63-79.

\section{ABSTRACT}

Tourism is often heralded as a force for peace, however, empirical research to confirm this suggestion is scant. To address this gap, this research integrates several datasets on conflict and tourism to examine whether a larger inflow of tourists makes civil conflict less likely. Several theoretical arguments of the role of tourism alongside other peace determining factors are presented. These inform the development of a probit model, and several specifications, that tests the hypothesis based on data from 126 countries and for the years from 1995 to 2010. The findings provide strong evidence that increasing tourism arrivals have a stabilising effect and increase the chance of peace. Implications for tourism and its role in the process of development are discussed.

Keywords: Peace; Conflict; Development; Governance; International tourist arrivals 


\section{INTRODUCTION}

The recent World Travel and Tourism Council (2016) report on peace and tourism highlights the industry's recognition of the important nexus between tourism and peace. The negative impacts of conflict on tourism are far reaching and result from reductions in tourist arrivals, which is either related to tourists' perceptions of safety and risk, and negative travel advisories, or directly to the loss of tourist attractions and infrastructure (Lepp et al., 2011). Conflict in the wider region is also problematic as seen in Jordan which reportedly suffers from conflict in neighbouring Syria (Taha, 2015). At the same time, tourism is known as a resilient industry (WTTC, 2016) that recovers quickly after conflict, making it an important tool in post-war reconstruction strategies (Alluri et al., 2014).

The majority of conflicts - as violent discord between the State and other internal groups are internal in nature and occur in less developed countries (Novelli et al., 2012 on fragile states, and Gleditsch et al., 2002 on a definition of conflict). Conflicts are often long-lasting and reoccurring; often within five years of signing a peace treaty (Smith, 2004). Peace is the process of reducing violence and achieving a balance of powers within overarching norms and institutions. The definition of peace depends on the particular perspective, but Rummel (1981) suggested that peace constitutes a more or less explicit, conscious and defined social contract, with different kinds of peace occurring at different social levels. 'Peacekeeping' has become increasingly complex, involving activities that contribute to ending the incidence of conflict, as well as preventing the onset of new conflict. Smith (2004) conceptualised peacekeeping to consist of four activities: providing security, establishing the socio-economic conditions for peace, establishing a peace-supporting political framework, and generating reconciliation through healing and implementing justice. Private sector actors are increasingly important in supporting peacekeeping. 
The notion of peace through tourism has been discussed since the 1920s, with 'Travel for Peace' as the theme of the 1929 British Travel and Holidays Association's inaugural conference (Wohlmuther \& Wintersteiner, 2014). Further milestones included the United Nation’s ‘Tourism: Passport to Peace’ year in 1967 and the 1980 declaration by the World Tourism Organization in Manila that, for the first time, highlighted tourism as a force for global peace. In 1986, Louis D‘Amore founded the International Institute for Peace through Tourism, based on the aspiration that tourism becomes the world's largest "peace industry" with every tourist being an “Ambassador for Peace” (Salazar, 2006). This was followed by several conferences, including one in Jordan in 2000 that produced the 'Amman Declaration on Peace through Tourism', formally adopted by the United Nations.

Meanwhile, the academic debate has advanced from a somewhat naïve approach to tourism as an instrument for peace based on the 'contact theory' (i.e. peace stemming from the cultural exchange of a positive host-guest encounter), to a more nuanced conceptualisation of ‘peace-sensitive tourism’ (Wohlmuther \& Wintersteiner, 2014). Tourism is often described as a social force that has the potential to lead to the democratisation of society and strengthen international relations towards non-violent conflict resolution (Kim et al., 2007). While recent years have seen increasing research interest in tourism and peace, several scholars drew attention to the difficulty of demonstrating a causal relation for tourism as a contributor to peace (Salazar, 2006), observing that "in the tourism and peace literature, we sometimes find confusion between normative goals and empirical facts” (Wohlmuther \& Winterstein, 2014, p. 52).

If the link between tourism and peace can be established, the implications are considerable (WTTC, 2016). The global tourism industry has expanded from 25 million international tourist arrivals in 1950 to 1,133 million in 2014. Most years have seen growth rates of over 4\% annually, with some world regions experiencing even higher growth. In 2014, emerging 
economies received $45.3 \%$ of all international arrivals globally (UNWTO, 2015), highlighting the importance of tourism as a development tool. Tourism is predicted to continue to grow, reaching an estimated 1.8 billion international arrivals in 2030 (UNWTO, 2011). With globally growing tourism volumes the opportunity presents itself to a wide range of countries to capitalise on tourism as part of their peacebuilding efforts.

To address the important knowledge gap of whether tourism contributes to peace, this research integrates several global datasets on conflict and tourism to examine the hypothesis of whether a larger inflow of tourists makes conflict less likely. The focus will be on the impact of tourism on the probability of civil conflict; that is, on the conflict that occurs internally to a country between the government and one or more opposition parties. Interstate conflicts between are not considered. In fact, empirically it would be difficult to study the two types of conflicts jointly as they are characterised by different determinants and dynamics. The choice then is to look at civil conflict because they are the most frequent form of armed conflict since World War II.

In a recent contribution, Pratt and Liu (2016) studied the two-way relationship between tourism and peace. Their research differs from this work in several respects. Conceptually, they focused on a notion of global peace that incorporates various dimensions of sociopolitical instability, while this research looks at the dichotomy between civil war and peace (in line with the voluminous political and economic literature on the causes of conflict). Methodologically, they used more parsimonious specifications and a shorter sample period than what is used here. Nevertheless, their finding that causality does not only run from peace to tourism, but could be reversed, is relevant to this paper. For one thing, it provides grounds for a more systematic assessment of the role of tourism as a determinant of peace. For another, it alerts to the statistical problem of identification. The central result of this paper is 
that, even after controlling for the possibility of reversed causality and other forms of endogeneity of tourism and peace, tourism does have a significant peace-stabilizing effect.

\section{THEORETICAL BACKGROUND}

\section{Tourism as a determinant of peace}

Regardless of whether tourism is seen as an industry or a social force, it is an activity that involves the movement of people for a range of purposes; supported by a multi-layered network of public and private sector stakeholders in both countries of origin and destination. Peace, safety and security are acknowledged ingredients of a successful tourism industry (WTTC, 2016). However, understanding the relationship between tourism and peace, both at a theoretical and practical level, is confounded by the ever-increasing global mobility, changing travel patterns, blurring boundaries between leisure, business and migration, and constant, but dynamic, global insecurity (Scott, 2012).

Despite conceptually vague boundaries, there is a widespread belief that tourism activity contributes to post-conflict stability (Novelli et al., 2012). This paper clarifies and quantifies the effect of tourism under the assumption that at any given point in time, a country can be in either of two situations: conflict or peace. The absence of one implies the occurrence of the other. Therefore, tourism promotes peace to the extent that it reduces the risk of conflict, whereby conflict is evidence of incompatibility between two parties where the use of armed forces lead to a minimum number of battle-related deaths. Thus, the corollary of the absence of conflict allows us to understand tourism's role in the peacekeeping process. It is acknowledged that even in the absence of armed conflict, a country might experience other forms of social unrest and/or dictatorship - however, these forms of 'conflict' are not covered in this research. 
Several arguments have been put forward, broadly in line with Smith’s (2004) peacebuilding dimensions, including tourism's ability to foster people-to-people understanding and hope, economic stimulus and development deriving from investment and tourist expenditure, and tourism as a catalyst for cooperation and partnerships.

\section{Inter-cultural understanding and education}

An increasing number of tourists are believed to be seeking responsible forms of tourism (Isaac, 2014). Against the background of wide-spread crises, D’Amore (2009) emphasised the particular importance of the emergent market of "peace tourism”, which includes travel to sites of significance to national or global peace, peace with others or nature, peace with past and future generations, and peace with one self. Visiting different countries and cultures has long been interpreted as a mind-broadening exercise that has the potential to enhance intercultural understanding and add positively to peace through the two-track diplomacy in which inter-government relations are complemented by people-focused exchanges (Kim et al., 2007; WTTC, 2016).

Conflict markers (e.g. war memorials) play an important role in managing post-conflict emotions (Novelli et al., 2012) and sharing of history and heritage. The contested nature of conflict-related events requires careful interpretation of history and the peace process to avoid that tourism opens up past or underlying animosity. Several researchers have highlighted the critical role tour guides play in achieving positive exchanges and education outcomes in postconflict regions (Isaac, 2014). To fulfil this role and navigate opposed constructions of conflict, cultural training of tour guides is critical (Friedl, 2014). It is therefore argued, that travel not only enhances cultural understandings of those who visit new places, but it has the potential to positively affect host communities in their reconciliation process. Isaac (2014) proposed that, based on the interactions with responsible travellers and the production of new 
knowledge, tourism can contribute to hope and new faith. As such tourism acts as a “confidence building measure” and a symbol of return to normality (Scott, 2012, p. 2114).

Economic stimulus and development

The importance of a functioning business environment for peace has been identified in earlier research, amongst others because viable businesses provide much needed taxation and enable the productive use of both human and other capital (Wohlmuther \& Wintersteiner, 2014). Case studies around the world indicate that tourism contributes, if not leads, the economic development following a conflict. The founding of the Sri Lanka First initiative in 2001 to lobby for peace through public campaigns has been put forward as an example of how the tourism industry proactively engaged in conflict reduction or avoidance (Alluri et al., 2014). Other examples criticised the dominance of business interests relative to peacebuilding initiatives. Research in Cyprus found that the political cooperation was largely driven by outside interests, moderated by the European Union and overseas tour operators, that put the tourism industry first and the advancement of peace second (Scott, 2012).

It is widely claimed that tourism contributes to development and poverty alleviation, with increasing incomes having a stabilising effect, especially in least developed countries (Novelli et al., 2014). Empirical evidence is provided through case studies, including research in Colombia that suggested that tourism-generated income and employment replaced illegal activities (e.g. drug trafficking), leading to increased self-confidence by local people and assisting in overcoming post-conflict trauma (Ramos, 2014). Tourism development initiatives were found to be successful if the local community is empowered from the onset of the project. Whilst tourism can have positive effects, tourism development also has the potential to exacerbate social tensions, inequality and conflict (Salazar, 2006; Timothy, 2013). 


\section{Cooperation for development}

Several studies have highlighted that the joint interest in developing a tourism industry has resulted in stakeholder cooperation that assisted a democratic peace-building process in postconflict countries (Causevic \& Lynch, 2013). Referring to Myanmar, Haeusler and Baumgartner (2014) described how a participatory tourism development policy and implementation not only laid the foundation for a sustainable tourism sector, but also assisted democratisation more broadly. At the same time it has been noted that some of the tourism dollars in Myanmar indirectly reinforce conflict as they assist the ruling powers and support activities by the military junta (Salazar, 2006). Elsewhere, however, the pivotal role of tourism in 'unifying' stakeholders around the goal of development was reinforced, including in Kenya in the context of ensuring tourist safety during elections (Lagat et al., 2014). Joint tourism training by the Ministry for Peace and Reconciliation of former 'enemies' in postconflict Burundi was highlighted as an example of the glue tourism can provide in the peacebuilding process (Novelli et al., 2012).

\section{Other determinants of peace}

In order to understand the effect of tourism it is important to account for other factors that might determine the incidence of conflict. Following Hegre and Sambanis (2006) it is possible to systematize the discussion by focussing on four key concepts that encompass most of the variables used in the literature to explain the occurrence of conflict (Blattman \& Miguel, 2010)

\section{Governance and institutional strength}

One heavily debated concept relates to the quality of the polity, broadly defined as the system of institutional checks and balances that regulate political processes in a country (e.g. competitiveness and openness in the recruitment of the executive and legislature, veto 
powers, etc.). It is argued that on the one hand, a strictly authoritarian regime reduces the opportunity of rebellion. On the other hand, in a near-perfect democracy, demands and grievances can be accommodated by institutional means and therefore the motive for rebellion is low. In intermediate regimes (e.g. semi-democracies), instead, the risk of conflict will be highest; implying that the relationship between quality of the polity and risk of conflict is expected to be inverted U-shaped (Gleditsch et al., 2007).

\section{Economic factors}

The second concept concerns the impact of economic factors. Traditionally, it has been argued that a higher level of per-capita Gross Domestic Product (GDP) reduces the risk of conflict in two ways. First, higher GDP means that the opportunity cost of conflict is higher (Collier \& Hoeffler, 2004). Second, higher GDP implies greater state capacity and hence ability to prevent rebellion (Fearon \& Laitin, 2003). The evidence in this second regard is somewhat ambiguous and has not always been robust to changes in the specification of the econometric model (Djankov \& Reynal-Querol, 2010). Furthermore, there are ambiguities at a theoretical level. In fact, the appropriation of economic wealth (i.e. greed) can be a powerful motive for fighting. To the extent that per-capita GDP is indicative of the potential reward from winning the conflict, its effect on the likelihood of conflict might be positive rather than negative. In addition, when more economic wealth is available, fighting parties might find it easier to finance their war efforts. This latter argument applies in particular to wealth generated from natural resources. ${ }^{1}$ On balance, the greed-effect is more likely to prevail in relatively poorer countries, while the effect associated with higher capacity and higher opportunity cost is likely to dominate in richer countries. This means that at low initial levels of per-capita GDP, an increase in per-capita GDP is expected to increase the likelihood

\footnotetext{
${ }^{1}$ The relationship between natural resources and civil conflict is part of the broader research programme on the curse of natural resources (see Koubi et al., 2014 on a comprehensive survey of this topic).
} 
of civil conflict. However, at sufficiently high initial levels, a further increase in per-capita GDP reduces the risk of conflict. Again, the relationship between per-capita GDP and the risk of conflict is supposed to be inverted U-shaped.

\section{Ethnicity}

The third broad concept used to explain civil conflict is ethnicity. The co-existence of different ethnic groups is often complicated by lack of mutual understanding, historical grievances, and unequal access to wealth and/or opportunities. This leads to the prediction that more ethnically divided countries are at higher risk of conflict. On empirical grounds, there is indeed evidence that ethnic heterogeneity increases the incidence of civil conflict (Montalvo \& Reynal Querol, 2005), particularly in countries where natural resources are more abundant (Wegenast \& Basedau, 2014) or governments have previously adopted policies to capitalize on the ascriptive nature of ethnicity (Wucherpfennig et al., 2012).

\section{Time dependence}

The concept of time dependence has also received considerable attention in previous work. Time dependence refers to the relationship between war/peace status at a given point in time and war/peace status in previous times. It is generally argued that peace is characterised by positive time dependence; that is, the risk of new conflict declines the longer the country has been at peace. This is because when a country is at peace, then peace-specific capital is accumulated while conflict-specific capital remains unused and hence quickly depreciates (e.g. Collier et al. 2008; Collier \& Hoeffler, 2004, Smith, 2004). By extension, one might also argue that the longer a conflict has lasted, the more likely it is that it will continue. However, the theoretical prediction is ambiguous. In fact, the cost of fighting does not necessarily decrease with the time spent in fighting and/or it decreases at different rate for different 
parties. If this is the case, then conflict might be characterised by negative (rather than positive) time dependence.

\section{METHOD}

This section introduces the model developed for this study, and provides information on the specific estimation approach and data sources used, namely data on civil conflict, international tourist arrivals, and other peace-determining variables.

\section{Model and estimation approach}

The hypothesis to be tested is that a larger inflow of tourism reduces the probability (or risk) of a country to be in a civil conflict - providing the necessary condition for peace. Let $y_{i t}$ be a binary indicator that takes value 1 if a civil conflict occurs in year $t$ in country $i$. Also, let $p_{\text {it }}$ be the probability that $y_{\text {it }}$ takes value 1 . The econometric model is formed by parametrizing $p_{\text {it }}$ to depend on a vector of attributes $\boldsymbol{x}$ :

(1) $p_{i t} \equiv \operatorname{Pr}\left(y_{i t}=1 \mid \boldsymbol{x}_{i t-k}^{\prime}\right)=\Phi\left(\boldsymbol{x}_{i t-k}^{\prime} \boldsymbol{\beta}\right)$

where $\Phi(\cdot)$ is the standard normal cumulative distribution function and $\boldsymbol{\beta}$ is a vector of coefficients to be estimated. Vector $\boldsymbol{x}$ includes a measure of tourism inflow and a group of control variables drawn from the concepts discussed earlier. The model allows tourism and the other variables to affect the probability of conflict with a lag of $k$ years (where $k$ is a nonnegative integer). Estimation is by maximum likelihood.

Unless otherwise indicated, $k$ will be set equal to one in the rest of the analysis, meaning that tourism inflows in year $t-1$ determine the probability of conflict in year $t$. The conceptual rationale for this choice is twofold. First, it takes time for the potential benefits of tourism to materialize after travellers have visited the country. Perceptions about economic opportunities or attitudes towards inter-cultural cooperation are processes that move 
relatively slowly, implying that one cannot expect an immediate impact of tourism on the peace process. Second, since peace stability is likely to generate more tourist arrivals, a contemporaneous correlation between arrivals and peace/war is difficult to interpret in terms of direction of causality (Pratt \& Liu, 2016). When tourism is lagged, then the risk of picking the reverse causality effect is reduced. A similar argument can be made for the other controls in the model. Operationally, there is no clear rule to choose a one year lag over a longer lag. Yet, given the relatively short time series of tourism data, longer lags would result in significant cut to the number of observations available for estimation. Sensitivity checks were run using $k=2$ and results turned out to be qualitatively very similar to those presented here.

With model (1), the marginal effect of the generic regressor $x_{z}$ is given by $\partial p / \partial x_{z}=$ $\phi\left(\boldsymbol{x}^{\prime} \boldsymbol{\beta}\right) \beta_{z}$, where $\phi$ is the standard normal density and $\beta_{z}$ is the estimated coefficient of regressor $x_{z}$. Hence, positive (negative) values of $\beta_{z}$ imply that increasing $x_{z}$ will increase (decrease) the probability of civil conflict (i.e. $y=1$ ). To facilitate the understanding of the quantitative effect of tourism, we complement the presentation of estimation results with a set of simulations that show how the probability of conflict changes for a given change in the inflow of tourism.

\section{Specification and data}

\section{Conflict data}

The dependent variable in the probit model $\left(y_{i t}\right)$ takes value 1 if a conflict occurs in country $i$ in year $t$ and zero otherwise. A conflict is defined as a contested incompatibility between the government of a state and one or more internal opposition groups (possibly with the intervention from other states on one or both sides) where the use of armed forces results in at least 25 battle-related deaths (Gleditsch et al. 2002). The information required to 
operationalize this definition is sourced from the Uppsala/PRIO Conflict database (htpps://www.prio.org/Data/). ${ }^{2}$

In the literature, the dependent variable is often coded as a one in the first year of a conflict, zero in peace years, and missing in years of ongoing conflict. This coding is meant to pick the onset of war. In this paper, instead, years of ongoing conflict are also coded as a one. The dependent variable therefore picks the incidence of conflict. The choice to focus on incidence rather than onset has a twofold motivation. First, the theoretical hypothesis put forward in this paper is that tourism reduces the likelihood of conflict at any given point in time, not just at the onset. Hence, incidence seems to be a more directly relevant concept. Second, with tourism data going back to 1995 only, the number of onsets is relatively small and hence the dependent variable would take value one too rarely.

Considering all countries in the Uppsala/PRIO database over the entire period 1960-2010, there are 786 conflict-years out of a total of 6,691 observations. This means that the unconditional probability of conflict is close to $12 \%$. This reduces to $8.4 \%$ over the period 1996-2010, which will be used for estimation in this paper. However, the panel of observations is unbalanced, in the sense that tourism, economics, and political data are not available for all countries and all years since 1996. Restricting attention to the sample that will effectively be used for estimation, the unconditional probability of conflict is $4.3 \%$.

\section{Tourism data}

Data on tourist arrivals stem from the UNWTO Compendium of Tourism Statistics (UNWTO, 2015). The UNWTO provides tourism statistics on 203 countries and territories

\footnotetext{
${ }^{2}$ Conceptually, we are defining peace as the absence of war, which justifies the use of a binary indicator for peace/war. Pratt \& Liu (2016) and WTTC (2016) measure peace with the Global Peace Index (GPI), which incorporates several different dimensions of external and internal socio-political stability on a five-point scale. Our preference for the binary indicator arises from three considerations: (i) we capture the intuitive idea that a country is either at peace or at (civil) war, (ii) we align with the extensive political and economic literature on conflict (see, inter alia, Bosker and De Ree, 2014; Carmignani and Kler 2016, and references therein), and (iii) we significantly extend the time dimension of our analysis (since GPI is available only for the period 2008-12).
} 
for the period 1995 to 2013. The Compendium has been produced annually since 1986, with the terminology having been revised slightly in 2005 and in 2010. The UNWTO obtains data from different sources (e.g. immigration statistics, accommodation data, traffic counts, and visitor surveys) compiled by country offices. The data on inbound tourism (including overnight arrivals of non-resident visitors and same-day excursionists crossing national borders) provides the most complete time series and was used in this study to construct the variable $z_{i t}$ in the probit model described above. Over the period of observation, the variable presents a very large dispersion. Its mean is 13.2 million arrivals, but the median is only 2.6 million and the standard deviation is 27.7 million. In fact, about $80 \%$ of all observations are located below the mean, which indicates that the distribution is heavily right skewed. In order to generate a more symmetric distribution, the original tourism series is transformed by taking its natural log. The resulting series has a mean of 14.9, median of 14.8 , standard deviation of 1.9 , and $52 \%$ observations fall below the mean. ${ }^{3}$

\section{Data for control variables}

Drawing on the discussion in the previous section on the determinants of conflict, the list of regressors in the probit model includes the following variables to capture polity, income, and ethnicity effects.

The concept of polity quality is measured by the competitiveness in the recruitment of the executive. This variable measures the extent to which the election or appointment of the government happens through an open, competitive, and transparent process. The variable is taken from the Polity IV Database ${ }^{4}$ and is constructed from experts’ assessment of the

\footnotetext{
${ }^{3}$. As a sensitivity check, the baseline model has been re-estimated using tourism arrivals per-capita and results are qualitatively very similar to those presented in Table 1 below. For instance, in the baseline regression, the estimated coefficient of tourism per-capita is -3.338 with a standard error of 1.002 , which implies that the coefficient is significant at the $1 \%$ confidence level. The estimated coefficient of the log of tourism per-capita is -0.513 , with a standard error of 0.095 , which again denotes statistical significance at the $1 \%$ confidence level.

${ }^{4}$ See http://www.systemicpeace.org/polityproject.html
} 
institutional and legal features of the recruitment process. Statistically, it is a number from 1 (non-competitive recruitment) to 8 (highly competitive recruitment). The sample mean is 5.6 and the median is 7 . The distribution is somewhat bi-model, with a peak around the value of 3 and another between 7 and 8. Just for reference, consider that countries like Albania (until 1989), Cameroon, Egypt, Indonesia (until 1998), Mexico (until 1993), and Tunisia are all ranked as three over most of the observation period. Examples of countries coded as 1 include Bahrain (from 1999 until 2010), Morocco (until 1976), and Saudi Arabia. At the other end of the spectrum, United States, United Kingdom, Australia, and the western European countries are all ranked as 8. Given that the effect of polity is likely to be nonlinear, a square value of the executive recruitment index was included.

Per-capita GDP is used as an indicator of economic conditions. The variable is taken from the Penn World Tables (Feenstra et al., 2015) and is expressed in constant prices to ensure comparability across countries. Similarly to tourism arrival, the distribution of per-capita GDP is right skewed (mean USD 8,541, median USD 3,701, standard deviation USD 12,510). Therefore, the variable is log transformed, and to account for the inverted U-shaped effect on the risk of conflict, the probit model also includes the squared valued of per-capita GDP.

Ethnicity is captured by the index of ethnic fractionalisation (Alesina et al., 2003), which measures the probability that two randomly selected individuals do not belong to the same ethnic group. Higher values denote greater fragmentation. Because ethnicity moves very slowly over time ,taking it as a country-specific fixed effect over a period of ten or twenty years is a reasonable approximation. The sample mean of ethnic fragmentation is 0.38 , the median is 0.35 and the standard deviation is 0.28 . Countries like Korea and Taiwan have ethnic fragmentation equal to 0; Cambodia, France, and New Zealand are in the range 0.110.15; Thailand, Belgium, and Botswana are in the range 0.35-0.38. Countries with highest 
ethnic fragmentation are Tanzania (0.89), Democratic Republic of Congo (0.87), Nigeria, (0.86), and Ivory Coast (0.85).

The time dependence concept is captured by a simple indicator that counts the cumulative number of years since the conclusion of the previous war. The coding of this indicator is again based on the information available from the PRIO/Uppsala conflict database. Lastly, the specification also includes the (natural log of) country’s population. The population variable is taken from Feenstra et al. (2015). After the log-transformation, the variable has a normal distribution, with both mean and median equal to 15.7 and standard deviation equal to $1.65 .^{5}$

\section{Limitations}

This research has several limitations. First, the model outputs are only as good as the data input. For example, the UNWTO tourism data are not of equal quality for all countries; however, UNWTO has been formally recognised by the United Nations as the most appropriate organisation to compile, standardise and integrate global tourism statistics. The UNWTO are universally accepted and represent the best available data set on arrivals. Second, tourism data are only available since 1995, which limits our ability to explore longer term dynamics. Both data quality and availability will improve over time. Third, the conceptual assumption that peace is the absence of measurable conflict is a limitation in the sense that countries that suffer other forms of suppression or non-violent conflict are treated as countries in peace when a broader definition might not agree with this assessment. Future models might take such additional states into account.

\footnotetext{
${ }^{5}$ Bilateral correlations between regressors are generally lower than 0.3 , i.e. the danger of multicollinearity is small. The correlation between GDP per-capita and tourism arrivals is, however, 0.6 and the correlation between arrivals and population is 0.5. To further examine these correlations, Variance Inflation Factors (VIF) were computed. The VIFs of GDP per-capita, population, and arrivals are respectively 4.7, 3.6 and 3.8, which is well below the suggested 10 (O’Brien, 2007).
} 


\section{RESULTS}

The size of the sample is determined by data availability. Tourism data were available from 1995 to 2013 for 126 countries, while GDP data from the Penn World Tables were available until 2010; thus the analysis refers to the timeframe 1995 to $2010 .{ }^{6}$ Conflict data were available for all of these countries since 1946, but some of the other variables were only obtainable for a subset of countries and over varying periods of time. The panel is therefore unbalanced. In addition, all the regressors are lagged by one year, which in practice pushes the start of the sample to 1996. The maximum number of observations available for estimation is 1,220 , which still ensures plenty of degrees of freedom for reliable statistical inference. The following presents a baseline model, followed by some more specific results of the marginal effect of tourism, and additional models to overcome potential effects of reverse causality of the tourism peace/conflict relationship.

\section{Baseline estimates}

Baseline results are reported in Table 1. Each column corresponds to a different version of the probit model. For each version, the table reports the estimated coefficients of tourism arrivals (i.e. $\beta_{1}$ in equation (2)) and the estimated coefficients of the other regressors (i.e. the $\beta_{\mathrm{m}}$ 's). The standard error and level of statistical significance of each estimate are also reported.

\section{TABLE 1 HERE}

\footnotetext{
${ }^{6}$ GDP data for the period 2011-2013 are available from other sources (e.g. World Development Indicators or the World Economic Outlook). However, the Penn World Tables is our preferred source as they provide data of the highest statistical quality, especially in terms of cross-country consistency and comparability. We did reestimate all of our models on the longer sample, 1996-2013, using the WEO data and found that the results are qualitatively the same as those discussed in the rest of this section.
} 
Column I of Table 1 reports estimates based on all observations. The central result is that the estimated coefficient of the tourism arrival variable is negative and statistically highly significant. This means that more arrivals in a given year reduce the probability that the country will be in conflict in the subsequent year. Because of the model set-up, the estimated coefficients cannot be given the standard partial derivative interpretation as in a linear regression model.

The remaining columns in Table 1 show that the result on the role of tourism is robust to various changes in the sample used for estimation and the specification of the model. In Column II, the sample excludes the most advanced economies as recipients of international arrivals (i.e. North America, Western Europe, Japan, Australia, and New Zealand). The underlying rationale is that advanced economies generally combine a low frequency of civil conflict with a higher capacity to attract tourists. Hence, their inclusion in the sample could bias results in favour of the hypothesis that tourism stabilises peace. As can be seen, the effect of tourism remains negative, statistically significant, and numerically even stronger than in the full sample estimates. This confirms that our findings are not just driven by an advanced countries effect. Even more importantly, the result in Column II confirms the tourism plays a potentially critical role in the development process. In Column III, the model is estimated on a sample that excludes some outliers. More specifically, the analysis of the distribution of tourism arrivals reveals that there is a small group of countries with very large numbers of international arrivals. Accordingly, the observations in the top $10 \%$ of the distribution are dropped from the sample. This however does not lead to any qualitative change in the impact of tourism on the risk of conflict. 
Estimates so far have considered the impact of arrivals in a given year on the risk of conflict the year after. However, it could be argued that tourism has a cumulative effect. In other words, the probability of conflict at time $t$ does not only depend on the inflow of tourists at time $t-1$, but also on arrivals in previous years (e.g. $t-2$, etc...). To account for this possible cumulative effect, the regression in Column IV is estimated using the sum of arrivals in the past five years as an explanatory variable. The estimated coefficient is now much larger than in Column I, suggesting that effectively the benefits of tourism are cumulative.

Column V allows for some persistence of the war/peace status over time by including a lagged dependent variable; that is, $y_{\mathrm{it}-1}$ is added to the set of regressors. Its positive coefficient intuitively suggests that the incidence of conflict is characterised by positive time dependence. In other words, being at war in the previous year increases the probability of being at war in the current year. Perhaps more importantly, the inclusion of the lagged dependent variable does not invalidate the hypothesis that tourism arrivals stabilize peace. The estimated coefficient of the tourism variable is, however, now considerably smaller than in Column I. This is not entirely surprising: the lagged dependent variable by construction accounts for a large proportion of the variation in the dependent variable. This in turn reduces the marginal impact of all other variables. As can be seen, the coefficients of all other regressors, including the constant term, also decline. ${ }^{7}$

\section{Other determinants of peace}

Generally speaking, the estimated coefficients align with theoretical expectations. The estimated coefficients of the polity and polity squared terms are indicative of a U-shaped relationship: given a continuum running from autocratic to democratic regimes, the risk of

\footnotetext{
${ }^{7}$ Additional robustness checks are available upon request. The inclusion of other regressors (domestic GDP growth, oil reserves per-capita, the proportion of mountainous terrain, and a dummy variable to isolate postconflict years) does not qualitatively change the findings concerning tourism. Also, dropping per-capita GDP and population one at the time does not significantly alter the estimated coefficient of tourism. This further confirms that estimates are not affected by multicollinearity. , .
} 
conflict is higher in intermediate regimes. The coefficient of years of peace is negative, meaning that the longer a country has been at peace, the less likely a conflict is. Population size instead has a positive effect on the risk of conflict. As previously noted, this is due to the fact that a threshold number of battle related deaths is used to define conflict, hence less populated countries are less likely to be at war. The positive coefficient of population could also suggest the existence of diseconomies of scale in preventing rebel's activities. From a government perspective, a larger population might be more difficult to monitor, for instance because disproportionately more resources have to be devoted to policing and prevention activities as the number of individuals or rebellious groups to be policed grows.

The role of ethnicity is more ambiguous. In accordance with the theory, the index of ethnic fragmentation has a positive coefficient (with the exception of the model with a lagged dependent variable), but this coefficient is only marginally statistically significant. In fact, the coefficient passes the zero restriction test of significance only in the full sample estimates and in the estimates without highly advanced economies. In the other versions of the model, the coefficient is not statistically different from zero, meaning that ethnic fragmentation does not significantly alter the probability of being in a conflict.

Lastly, there is also some ambiguity with respect to the role of per-capita GDP. The full sample estimates, the model without outliers, and the model with five year cumulative arrivals all indicate that per-capita GDP affects the probability of conflict non-linearly and that this non-linear effect is inverted-U shaped. This finding does support the above theoretical discussion, but is not robust to dropping the advanced economies from the sample of estimation. In fact, advanced economies are systematically characterised by a combination of high income and low risk of conflict. This in turn might imply that when they are dropped from the sample, then the squared term of per-capita GDP becomes redundant. The results for 
per-capita GDP are also not robust to the inclusion of the lagged dependent variable, which is an issue that probably deserves attention in some future research.

\section{Panel and two-stage estimates}

This subsection considers two extensions of the econometric model. The first one is the estimation of an effects model. The effects model takes advantage of the panel structure of the dataset to allow for unobserved country specific effects. In a random effects model, this unobserved country heterogeneity is assumed to be uncorrelated with the regressors. This orthogonality assumption is removed in a fixed effects model. However, the fixed effects model is not suitable here, because for a number of countries in the sample the binary outcome $y_{\text {it }}$ is always zero. These countries would have to be dropped from the sample, which is clearly undesirable as it would result in sample selection bias. Moreover, the use of a fixed effect would imply that the time-invariant measure of ethnic fragmentation has to be excluded from the set of regressors.

The baseline model with random effects estimated on the full sample of all observations is reported in Column I of Table 2. The level of statistical significance of per-capita GDP and polity drops considerably compared to the estimates in Column I of Table 1 . However, there is still very strong evidence of a peace stabilizing effect of tourist arrivals, with the effect being much stronger than what was observed in baseline estimates. An additional table on random effects that confirms that a larger inflow of tourists significantly reduces the risk of civil war is available on request.

\section{TABLE 2 HERE}

The second econometric extension addresses any residual concerns about the potential endogeneity of tourism arrivals and war/peace status. The standard approach to the treatment of endogeneity relies on the use of instrumental variables to isolate the exogenous variation in 
the endogenous regressors. Once a suitable instrument is identified, estimation typically proceed in two steps: first the endogenous variable is regressed on the instrument and the other exogenous regressors, then the original regression is run using fitted values of the endogenous variable from the first stage.

In our case, to be suitable as an instrument, a variable must be correlated with tourism arrivals, exogenous to the risk of conflict, and correlated to the risk of conflict only through its effect on tourism arrivals. Based on the comprehensive literature on tourist arrivals models (e.g. Schiff \& Becken, 2011; Song et al., 2003), and the identified strong link between Gross Domestic Product and tourism demand (Pērez-Rodríguez et al., 2015), global economic growth seems to be a likely candidate in this regard. However, more than with the level of tourism arrivals, it is probably correlated with the growth in tourism arrivals; that is, global economic growth is a potentially good instrument for the average growth of tourism across countries. ${ }^{8}$ In our regression model tourism arrivals are expressed in levels, and we therefore need to modify the standard two-step approach as follows.

Step one now consists of estimating an OLS regression of the growth in tourism arrivals on the growth rate of the global economy (and possibly other determinants of tourism arrivals). The estimated coefficients of this equation are used to obtain fitted values of the growth rate of tourism arrivals in each year. Setting the starting level of tourism arrivals to the actual value observed in 1995, the fitted growth rates are then recursively applied to generate an estimated series of levels of tourism arrivals. In step two, these estimated levels are used in place of the original series of tourism arrivals to run the probit model. Bootstrapping is used to ensure that the second-step standard errors are robust (e.g. see Ashraf \& Galor, 2013).

\footnotetext{
${ }^{8}$ Our argument is that tourism flows are a function of global economic conditions so that on average, tourism arrivals in a country tend to increase faster the higher the rate of world GDP growth (see UNWTO, 2011). When directly included in the baseline regression of Column I, Table 1, global growth fails to be statistically significant (even after dropping tourism). This suggest that global growth does not directly affect the risk of civil war. However, as shown below, its statistical correlation with tourism growth is strong, which is what is needed to implement our estimation procedure.
} 
Columns II and III of Table 2 report the estimates obtained from the two-step procedure. The first step regression is very parsimonious as it only includes a constant and global growth. It is worth stressing that the estimated coefficient of global growth is positive and strongly significant, confirming that growth in tourism arrivals is determined by global economic conditions. In step-two, the coefficient of the estimated tourism arrivals variable is once again negative, statistically significant, and numerically similar to the one obtained in the baseline estimates. As the generated tourism arrivals are obtained from an exogenous source of variation like global growth, they are most likely exogenous to the probability of conflict so that the estimated coefficient can effectively be taken as representing a causality effect.

Columns IV and V repeat the same two-step exercise, with the difference that the first step equation now includes a number of additional variables which might determine both the risk of conflict and tourism arrivals. For the purpose of the validity of the method, what really matters is that global growth in the first step regression continues to be positive and significant. The second stage results further support the conclusion that there is indeed a causal effect from tourism to the risk of conflict. ${ }^{9}$

Three statistical diagnostics are reported at the bottom of Columns III and V (details in the notes to Table 2). The first diagnostic (Hausman specification test) favours the baseline estimates in Table 1 over the two-step estimates in Table 2, which are however consistent. The Chi-square statistic and F statistic diagnostics (Angrist \& Pischke, 2009) indicate that tourism growth is robustly identified in the first step regression.

\footnotetext{
${ }^{9}$ The first step regression was also run using all the regressors included in the second step. The estimated coefficient of global growth was 0.016 (s.e. 0.003). In the second step regression, the estimated coefficient of tourism arrivals was -0.512 (s.e. 0.008). Population, ethnicity and the squared terms of polity and per-capita GDP were all not significant in the first step regression. This supports the exclusion restrictions embedded in Column IV of Table 2.
} 


\section{Quantifying the effect of tourism on the risk of conflict}

The estimated coefficient of tourism arrivals in Tables 1 and 2 can be readily interpreted in terms of positive/negative effect and statistical significance. A more precise quantitative interpretation is, however, complicated by the fact that the dependent variable is not linear and the tourism arrivals variable is log-transformed. Therefore, in order to provide some quantitative understanding of the strength of the effect, this subsection compares the estimated probability of conflict for different levels of arrivals. The probabilities are fitted with values obtained from the baseline estimates in Column I (Table 1). Three sets of probabilities are computed: one based on the actual number of arrivals, one assuming 20\% more arrivals in each year, and one assuming 50\% more arrivals in each year. So, the only difference between the three probabilities is the number of arrivals. This means that a comparison of the three probabilities should provide an assessment of the reduced risk of conflict associated with a $20 \%$ and a $50 \%$ increase in arrivals in each country.

The average fitted probability of conflict in the full sample is $4.1 \%$. This declines to $3.6 \%$ when arrivals are increased by $20 \%$ and it further decreases to $3.1 \%$ when arrivals are increased by $50 \%$. In other words, the probability of conflict declines by approximately $12 \%$ in response to a $20 \%$ increase in arrivals and by approximately $24 \%$ in response to a $50 \%$ increase in arrivals. It is important to consider that many countries in the sample have probability of conflict close to 0 . For these, the impact of increased arrivals is not particularly evident. More insightful, instead, is it to focus on countries that experience prolonged spells of conflict. Two countries that have seen repeated conflict, but also an increase in tourism arrivals are used here to illustrate the effects of tourism arrivals in terms of reduced conflict probability. 
Figures 1 and 2 plot the probabilities of conflict in Russia and Sri Lanka. It can be seen that in Russia, the average probability of conflict decreases from $20 \%$ to $17 \%$ when arrivals increase by $20 \%$ and to $15 \%$ when arrivals increase by 50\%. Secondly, in Sri Lanka $20 \%$ more arrivals lower the risk of conflict from $15 \%$ to $13 \%$ while $50 \%$ more arrivals bring the probability of conflict down to $11 \%$. In summary, tourism does not in itself eliminate the risk of conflict in countries that are more vulnerable to violence, but it does help achieve a sizeable reduction in risk.

\section{FIGURES 1-2}

\section{DISCUSSION AND CONCLUSIONS}

This research integrated data on tourist arrivals with a global database on civil conflict to examine whether increased levels of arrivals reduce the likelihood of conflict. Theoretically, tourism can be grounds for peace or a beneficiary of peace and recent empirical evidence (Pratt \& Liu, 2016) shows that the two effects co-exist. To isolate the direction of causality and identify the effect of tourism on peace, the econometric model was estimated using lagged values of tourism and other regressors. In addition, an exogenous source of variation in tourism was used to validate the findings. Results consistently indicated that larger tourism inflows reduce the probability of conflict. This finding was robust to various sensitivity checks, including the estimation of a dynamic model where the current risk of civil war depends on its past values. Thus, this research shows that the peace stabilising role of tourism is not just hypothetical.

The extent to which tourism contributed to reducing the risk of conflict has been explored hypothetically for Russia and Sri Lanka. Assuming yearly international tourism arrival growth rates of $20 \%$ and $50 \%$, the likelihood of conflict reduced substantially, for example in the order of $13 \%$ for a $20 \%$ increase in arrivals to Sri Lanka. These scenarios highlight the 
considerable potential that tourism might bring to fragile states (Novelli et al., 2012). Sri Lanka, for example, demonstrated consistent tourism growth from 549,000 arrivals in 2005 to 1,527,000 in 2014 - testimony to concerted efforts by both the private and public components of the Sri Lanka tourism sector (Alluri et al., 2014). These numbers are promising; although, at a closer look tourism activity in Sri Lanka remains geographically confined to the west and south and underdeveloped in the conflict zones of the north. The uneven distribution of benefits and ongoing 'pockets of conflict' are possibly not uncommon in larger, more populous countries, as also indicated in the finding of a positive relationship between population size and conflict.

Longer-term tourism growth provides a positive cumulative effect, as shown in this research. This is particularly pertinent, considering that the risk of re-occurring conflict is highest in the years immediately after establishment of peace (Smith, 2004). Thus, stimulation of tourism in a post-conflict situation is important, but consistent investment over many years is even more critical to reap the peace-bringing effects (Fearon \& Laitin, 2003). Once a timeframe of 10 years of peace has been reached the likelihood of conflict becomes small (Collier et al., 2008). Several examples exist in the literature of how Governments prioritised tourism development (e.g. by demining national parks in Rwanda, Alluri et al., 2014) as a means to bringing back economic activity and 'normality' (Scott, 2012). A more indirect effect of tourism development may come from an improved country image due to tourism promotion (Lepp et al., 2011).

Rebuilding tourism in a post-conflict country presents opportunities, most prominently for poverty alleviation and social equity. Research on the benefits and pitfalls of tourism in developing countries points towards a wide range of socio-economic benefits for communities (Buzinde et al., 2014). The recognised potential of tourism to provide employment opportunities, in particular for women, has been specifically highlighted in the 
context of peacebuilding processes, given that conflict often reduces the number of male workforce, putting more pressure on women to contribute to the reconstruction (Alluri et al., 2014). (Re)-developing tourism after conflict should aspire to focus on those initiatives that provide long-lasting, sustainable, inclusive and resilient outcomes. Such higher-level goals are in line with the new Sustainable Development Goals (UN, 2015).

Questions of equity may then also consider the current distribution of tourism globally. At present, most tourism occurs in Western countries: Europe alone received 51\% of global arrivals in 2014, with the United States of America attracting 74.8 million (or 6.6\%) international arrivals annually. Considering that most tourist departures are from Western countries, global travel is mainly a North-North phenomenon; in other words facilitating economic benefits amongst already developed nations. Most recent data from the UNWTO (2015) indicate that tourism growth in emerging economies has slowed down somewhat and also receives relatively less economic benefit from tourism. In 2014, emerging economies received $45.3 \%$ of international arrivals but only $34.5 \%$ of international receipts from tourism. Global efforts towards enhancing North-South travel, for example through the UNWTO’s Sustainable Tourism for Eliminating Poverty program, may not only address economic issues, but could also contribute positively to peace.

Tourism's contribution to peacebuilding and development is best harnessed as part of a broader government-led strategy. Our findings reinforce the importance of transparent governance schemes for peace (Gleditsch et al., 2007). In the context of tourism, the importance of strong institutional arrangements for the country's ability to leverage peacecontributing potentials from tourism was highlighted earlier (e.g. Alluri et al, 2014; Novelli et al., 2012; Scott, 2012). If unsupported by broader peace building strategies (Smith, 2004), the private tourism industry, tends to pursue a (passive) principle of 'doing no harm', rather than actively promoting transformational change or peace-building initiatives (Alluri et al., 2014). 
Lack of public sector support and strategy may then even lead to proliferation of negative impacts from tourism (Salazar, 2006).

Several examples have been advanced that illustrated how private-public sector disconnect can lead to undesirable outcomes. The lack of an encompassing strategy for tourism development and cooperation in Bosnia-Herzegowina, for example, was highlighted as one factor in the failure of capitalising on tourism as a vehicle for reconciliation. More specifically, Causevic and Lynch (2013) suggested that the Dayton Agreement on which post-conflict Bosnia-Herzegowina is built and which favours ethnic enclaves, should be amended to allow the development of a tourism strategy and national promotion, as part of a much needed trust-building process. The mere 'absence of war' is insufficient to build a thriving tourism sector or to establish 'positive peace' (i.e. the institutional integration of peace into governance systems). Similarly, Kim et al. (2007) noted that the positive effect of an emerging two-track diplomacy resulting from South Korean's travel to selected sites in North Korea can be eroded through less supportive relations at the Government level.

More generally, the evidence presented here hints at a broader set of relationships linking tourism and development. Tourism dynamically interacts with other macroeconomic, political, and institutional factors to determine development outcomes. The relative contribution of tourism to progress on any dimension of the development process is likely to be conditional on the underlying socio-economic policy framework. In other words, different policy frameworks might be more or less adequate to unleash the potential beneficial effects arising from tourism (in achieving peace or other desirable outcomes). The challenge for policymakers and researchers is then to understand which policies strengthen or weaken the effect of tourism and, in reverse, how tourism can amplify the effect of other socio-economic policies. In empirical terms, this will require the use of systems of simultaneous equations that incorporate suitable non-linearities and/or interactive effects between tourism and 
relevant policy factors. This is certainly a stimulating avenue of future research, as is further investigation of the tourism-peace relationship in different world regions. 


\section{REFERENCES}

Alesina, A., Devleeschauwer, A., Easterly, W., Kurlat, S. \& Wacziarg, R. (2003). Fractionalization. Journal of Economic Growth, 8(2), 155-194.

Alluri, R. M., Lei Cher, M., Palme, K. \& Ke Joras, U. (2014). Understanding Economic Effects of Violent Conflicts on Tourism: Empirical Reflections from Croatia, Rwanda and Sri Lanka. Pp. 101-119. In: Wohlmuther, C. \& Wintersteiner, W. (Eds.). International Handbook on Tourism and Peace. Drava Verlag: Klagenfurt.

Angrist, J. \& Pischke, J. (2009). Mostly Harmless Econometrics: An Empiricist’s Companion. Princeton: Princeton University Press.

Ashraf , Q \& Galor, O. (2013). The “Out of Africa” Hypothesis, Human Genetic Diversity, and Comparative Economic Development. American Economic Review, 103(1), 1-46.

Blattaman, C. \& Miguel, E. (2010). Civil War. Journal of Economic Literature, 48(1), 3-57.

Bosker, M. \& de Ree, J. (2014). Ethnicity and the spread of civil war. Journal of Development Economics 108 (2014), 206-221.

Buzinde, C.N., Kalavar, J.M. \& Melubo, K. (2014). Tourism and community well-being: The case of the Maasai in Tanzania. Annals of Tourism Research, 44, 20-35.

Carmignani, F. \& Kler, P. (2016). The spillover of war in time and pace: exploring some open issues. Applied Economics, forthcoming.

Causevic, S. \& Lynch, P. (2013). Political (in)stability and its influence on tourism development. Tourism Management, 34, 145-157.

Collier, P. \& Hoeffler, A. (2004). Greed and grievance in civil war. Oxford Economic Papers, 56(4), 563-595. 
Collier, P., Hoeffler, A. \& Soderbom, M. (2008). Post-conflict risks. Journal of Peace Research, 45(4), 461-478.

D’Amore, L. (2009). Peace through Tourism: The Birthing of a New Socio-Economic Order. Journal of Business Ethics, 89(4), 559-568.

Djankov, S. \& Reynal-Querol, M. (2010). Poverty and civil war: revisiting the evidence. The Review of Economics and Statistics, 92(4), 1035-1041.

Fearon, J. \& Laitin, D. (2003). Ethnicity, insurgency and civil war. American Political Science Review, 97(1), 75-90.

Feenstra, R., Inklaar, R. \& Timmer, P. (2015). The next generation of the Penn World Table. Forthcoming American Economic Review. Available (20/01/16) www.ggdc.net/pwt.

Friedl, H. (2014). “I Had a Good Fight with my Buddy!” Systemic Conflict Training in Tourism Education as a Paradigmatic. Approach to Stimulating Peace Competence. Pp. 335-354. In: Wohlmuther, C. \& Wintersteiner, W. (Eds.). International Handbook on Tourism and Peace. Drava Verlag: Klagenfurt.

Gleditsch, N., Hegre, H. \& Strand, H. (2007). Democracy and civil war. Pp. 155-192. In: Midlarsky, M. (Ed.). Handbook of War Studies III. Ann Arbor, MI: University of Michigan Press.

Gleditsch, N., Wallensteen, P., Eriksson, M., Sollenberg, M. \& Strand, H. (2002). Armed conflict: 1946-2001. Journal of Peace Research, 39(5), 615-637.

Häusler, N. \& Baumgartner, C. (2014). Myanmar on its Way to Responsible Tourism Management: The Important Role of Stakeholder Dialogues. Pp. 181-198. In: 
Wohlmuther, C. \& Wintersteiner, W. (Eds.). International Handbook on Tourism and Peace. Drava Verlag: Klagenfurt.

Hegre, H. \& Sambanis, N. (2006). Sensitivity analysis of empirical results on civil war onset. Journal of Conflict Resolution, 50(4), 508-535

Hosmer, D., Lemeshow, S. \& Sturdivant, R. (2013). Applied Logistic Regression. 3rd ed. Hoboken, NJ: Wiley.

Kim, S.S., Prideaux, B. \& Prideaux, J. (2006). Using tourism to promote peace on the Korean Peninsula. Annals of Tourism Research, 34(2), 291-309.

Koubi, V., Spilker, G., Bohmelt, T. \& Bernauer, T. (2014). Do natural resources matter for interstate and intrastate armed conflict? Journal of Peace Research, 51(2), 227-243.

Lagat, K., Kiarie, S.W. \& Njiraini, P. (2014). Tourism and Peace: The Role of Election Period Tourism Operating Procedures in Promoting Peaceful Elections in Kenya. Pp. 199-215. In: Wohlmuther, C. \& Wintersteiner, W. (Eds.). International Handbook on Tourism and Peace. Drava Verlag: Klagenfurt.

Lepp, A., Gibson, H. \& Lane, C. (2011). Image and perceived risk: A study of Uganda and its official tourism website. Tourism Management, 32(3), 675-684.

McFadden, D. L. (1974). Conditional logit analysis of qualitative choice behavior. Pp. 105142. In: Zarembka, P. (Edt). Frontiers in Econometrics. New York: Academic Press.

Montalvo, J. \& Reynal Querol, M. (2005). Ethnic polarization, potential conflict, and civil wars. American Economic Review, 95(3), 796-816.

Novelli, M., Morgan, N. \& Nibigira, C. (2012). Tourism in a post-conflict situation of fragility. Annals of Tourism Research, 39(3), 1446-1469. 
O’brien, R. M. (2007). A caution regarding rules of thumb for variance inflation factors. Quality \& Quantity 41, 673-690.

Pērez-Rodríguez, J.V., Ledesma-Rodríguez, F. \& Santana-Gallego, M. (2015). Testing dependence between GDP and tourism's growth rates. Tourism Management, 48, 268282.

Pratt, S. \& Liu, A. (2016). Does Tourism Really Lead to Peace? A Global View. International Journal of Tourism Research, 18, 82-90.

Ramos, N. (2014). Communitarian Ecotourism in the Colombian Darién and Urabá Region: An Opportunity for Peace-Building. Pp. 143-154. In: Wohlmuther, C. \& Wintersteiner, W. (Eds.). International Handbook on Tourism and Peace. Drava Verlag: Klagenfurt.

Rummel, R.J. (1981). Understanding Conflict and War. The Just Peace. Vol. 5. Beverly Hills, California: Sage Publications.

Salazar, N.B. (2006). Building a ‘Culture of Peace’ through Tourism: Reflexive and analytical notes and queries. Universitas humanística, 62, 319-333. Available $(31 / 07 / 15)$ http://www.javeriana.edu.co/Facultades/C_Sociales/universitas/62/salazar.pdf

Schiff, A. \& Becken, S. (2011). Demand Elasticities for Tourism in New Zealand. Tourism Management, 32(3), 564-575.

Scott, J. (2012). Tourism, civil society and peace in Cyprus. Annals of Tourism Research, 39(4), 2114-2132. 
Smith, D. (2004). Towards a strategic framework for peacebuilding: Getting their act together. Overview report of the Joint Utstein Study of Peacebuilding. Available (20/07/15) http://odin.dep.no/ud/engelsk/publ/rapporter/032091-990133/

Song, H., Witt, S.F. \& Li, G. (2003). Modelling and forecasting demand for Thai tourism. Tourism Economics, 9(4), 363-387.

Stock, J. \& Yogo, M. (2005). Testing for Weak Instruments in Linear IV Regression. In D.W.K. Andrew and J. H. Stock (Eds). Identification and Inference for Econometric Models: Essays in Honor of Thomas Rothenberg. Cambridge: Cambridge University Press.

Taha, K. (2015). Jordan battling to rescue key tourist sector from regional fallout. Middle East Eye. 21 July 2015. Available (01/08/15) www.middleeasteye.net/topics/insidejordan

Timothy, D. J. (2013). Tourism, war and political instability. Territorial and religious perspectives. Pp. 12-25. In: Butler, R. \& Suntikul, W. (eds). Tourism and War. London: Routledge.

United Nations World Tourism Organisation (2011). Tourism Towards 2030: Global overview. Available (12/11/13) http://cestur.sectur.gob.mx/descargas/Publicaciones/Boletin/cedoc2012/cedoc2011/unw to2030.pdf

United Nations World Tourism Organisation (2015). Compendium of Tourism Statistics. Methodological notes. Available (1/08/15) http://dtxtq4w60xqpw.cloudfront.net/sites/all/files/pdf/2015_metho_notes_eng.pdf 
Wegenast, T. \& Basedau, M. (2014). Ethnic fractionalization, natural resources and armed conflict. Conflict Management and Peace Science, 31(4), 432-457.

Wohlmuther, C. \& Wintersteiner, W. (Eds.) (2014). International Handbook on Tourism and Peace. Drava Verlag: Klagenfurt.

World Travel and Tourism Council (2016). Tourism as a Driver of Peace. Available $(12 / 05 / 16)$ www.wttc.org

Wucherpfennig, J., Metternich, N., Cederman, L. \& Gleditsch, K. (2012). Ethnicity, the state, and the duration of civil wars. World Politics, 64(1), 79-115. 
Table 1: Baseline results

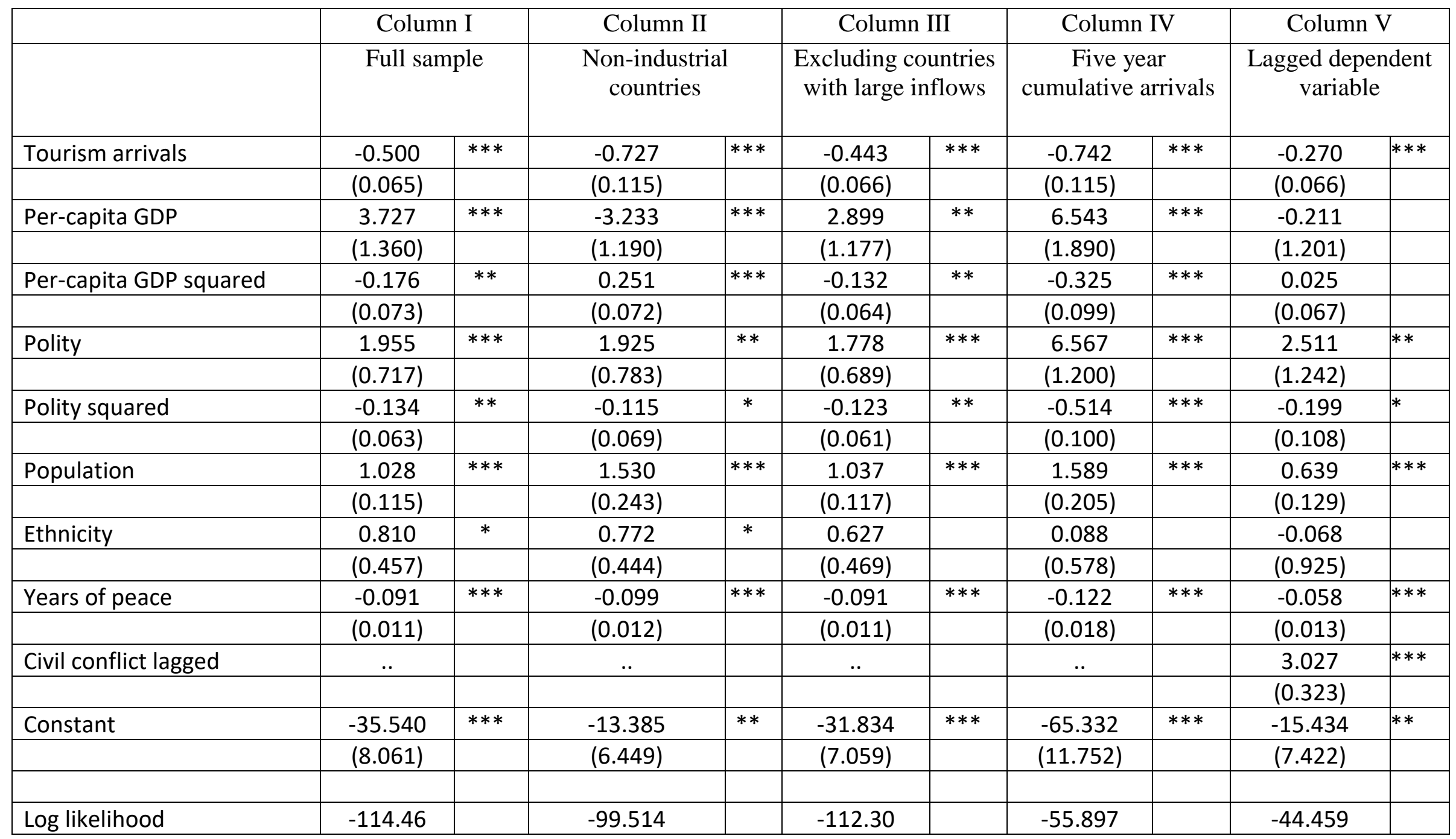




\begin{tabular}{|c|c|c|c|c|c|}
\hline $\begin{array}{l}\text { LR statistic } \\
\text { (p-value) }\end{array}$ & $\begin{array}{l}194.74 \\
(0.000) \\
\end{array}$ & $\begin{array}{l}207.67 \\
(0.000) \\
\end{array}$ & $\begin{array}{l}187.59 \\
(0.000) \\
\end{array}$ & $\begin{array}{l}111.27 \\
(0.000)\end{array}$ & $\begin{array}{l}334.75 \\
(0.000) \\
\end{array}$ \\
\hline Pseudo R2 & 0.459 & 0.511 & 0.455 & 0.498 & 0.790 \\
\hline $\begin{array}{l}\text { Pearson chi-square } \\
\text { (p-value) }\end{array}$ & $\begin{array}{l}59.24 \\
(0.57)\end{array}$ & $\begin{array}{l}56.43 \\
(0.59)\end{array}$ & $\begin{array}{l}57.61 \\
(0.57)\end{array}$ & $\begin{array}{l}55.44 \\
(0.62)\end{array}$ & $\begin{array}{l}51.38 \\
(0.69)\end{array}$ \\
\hline $\begin{array}{l}\text { Hosmer Lemeshow chi- } \\
\text { square } \\
\text { (p-value) }\end{array}$ & $\begin{array}{c}4.46 \\
(0.49)\end{array}$ & $\begin{array}{c}4.18 \\
(0.51)\end{array}$ & $\begin{array}{c}4.39 \\
(0.49)\end{array}$ & $\begin{array}{c}4.07 \\
(0.55)\end{array}$ & $\begin{array}{c}3.63 \\
(0.59)\end{array}$ \\
\hline Observations & 1220 & 1037 & 1093 & 809 & 1220 \\
\hline
\end{tabular}

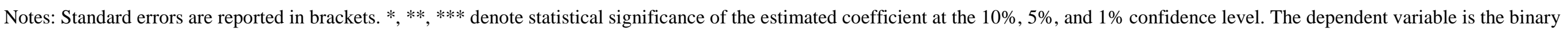

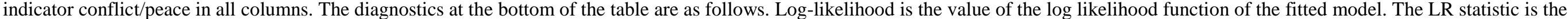

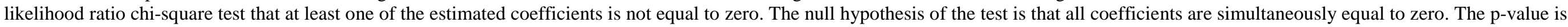

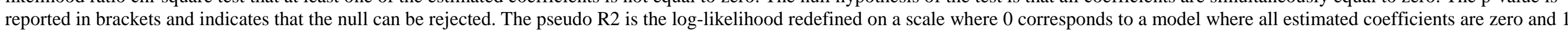

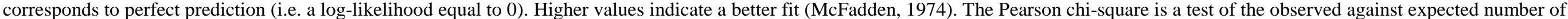

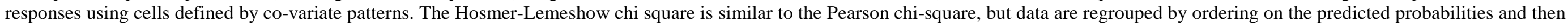

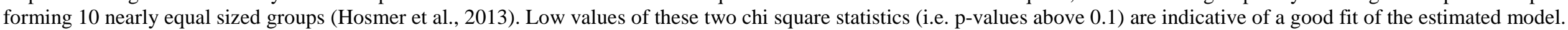


Table 2: Regressions with generated value of tourism arrivals

\begin{tabular}{|c|c|c|c|c|c|c|c|c|c|c|}
\hline \multirow[b]{2}{*}{$\begin{array}{l}\text { Tourism arrivals } \\
\text { (generated) }\end{array}$} & \multicolumn{2}{|c|}{$\begin{array}{l}\text { Column I } \\
\text { (panel } \\
\text { estimates) }\end{array}$} & \multicolumn{2}{|c|}{$\begin{array}{l}\text { Column II } \\
\text { First stage }\end{array}$} & \multicolumn{2}{|c|}{$\begin{array}{l}\text { Column III } \\
\text { Second stage }\end{array}$} & \multicolumn{2}{|c|}{$\begin{array}{l}\text { Column IV } \\
\text { First stage }\end{array}$} & \multicolumn{2}{|c|}{$\begin{array}{c}\text { Column V } \\
\text { Second stage }\end{array}$} \\
\hline & -0.865 & $* * *$ & .. & & -0.407 & $* * *$ & .. & & -0.480 & $* * *$ \\
\hline & $(0.326)$ & & & & $(0.059)$ & & & & $(0.074)$ & \\
\hline \multirow[t]{2}{*}{ Per-capita GDP } & 6.939 & & .. & & 2.660 & $* *$ & -0.115 & $* *$ & 4.717 & $* * *$ \\
\hline & (6.984) & & & & (1.194) & & $(0.045)$ & & $(1.787)$ & \\
\hline \multirow[t]{2}{*}{ Per-capita GDP squared } & -0.391 & & .. & & -0.119 & $*$ &.. & & -0.229 & $* *$ \\
\hline & $(0.428)$ & & & & $(0.065)$ & & & & $(0.094)$ & \\
\hline \multirow[t]{2}{*}{ Polity } & 2.618 & & .. & & 2.182 & $* * *$ & 0.008 & & 2.398 & $* * *$ \\
\hline & $(2.963)$ & & & & $(0.694)$ & & $(0.009)$ & & $(0.749)$ & \\
\hline \multirow[t]{2}{*}{ Polity squared } & -0.132 & & .. & & -0.153 & $* *$ & .. & & -0.174 & $* * *$ \\
\hline & $(0.263)$ & & & & $(0.061)$ & & & & $(0.066)$ & \\
\hline \multirow[t]{2}{*}{ Population } & 2.231 & $* * *$ & .. & & 0.901 & $* * *$ & .. & & 1.004 & $* * *$ \\
\hline & $(0.718)$ & & & & $(0.106)$ & & & & $(0.125)$ & \\
\hline \multirow[t]{2}{*}{ Ethnicity } & 1.829 & & .. & & 0.378 & & .. & & 0.221 & \\
\hline & $(3.351)$ & & & & $(0.461)$ & & & & $(0.467)$ & \\
\hline \multirow[t]{2}{*}{ Years of peace } & -0.240 & $* * *$ &.. & & -0.089 & $* * *$ & 0.002 & & -0.094 & $* * *$ \\
\hline & $(0.082)$ & & & & $(0.011)$ & & $(0.002)$ & & $(0.012)$ & \\
\hline \multirow[t]{2}{*}{ Global growth } &.. & & 0.020 & $* * *$ &.. & & 0.014 & $* * *$ &.. & \\
\hline & & & $(0.003)$ & & & & $(0.003)$ & & & \\
\hline \multirow[t]{2}{*}{ Domestic growth } & .. & & .. & & .. & & 0.678 & $* * *$ & .. & \\
\hline & & & & & & & (0.141) & & & \\
\hline \multirow[t]{3}{*}{ Constant } & -66.279 & $* * *$ & -0.021 & & -30.325 & $* * *$ & 0.892 & $* *$ & -40.687 & $* * *$ \\
\hline & (34.645) & & $(0.013)$ & & $(7.147)$ & & $(0.359)$ & & $(10.090)$ & \\
\hline & & & & & & & & & & \\
\hline
\end{tabular}




\begin{tabular}{|c|c|c|c|c|c|}
\hline $\begin{array}{l}\text { Hausman specification test } \\
\text { ( } p \text { value) }\end{array}$ & .. & .. & $\begin{array}{c}1.82 \\
(0.17)\end{array}$ & .. & $\begin{array}{c}2.22 \\
(0.13)\end{array}$ \\
\hline $\begin{array}{l}\text { AP Chi-squared test stat } \\
\text { ( } p \text { value) }\end{array}$ & .. & .. & $\begin{array}{c}35.72 \\
(0.000) \\
\end{array}$ & .. & $\begin{array}{c}18.11 \\
(0.000) \\
\end{array}$ \\
\hline $\begin{array}{l}\text { AP F statistic } \\
\text { (Stock-Yogo Critical Value) }\end{array}$ & .. & .. & $\begin{array}{c}35.66 \\
(16.38)\end{array}$ & .. & $\begin{array}{c}17.24 \\
(16.38) \\
\end{array}$ \\
\hline Number of observations & 1220 & 1224 & 1123 & 1195 & 1085 \\
\hline
\end{tabular}

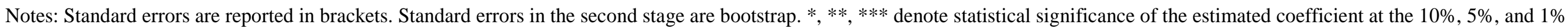

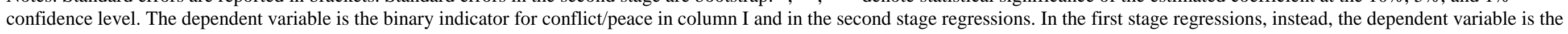

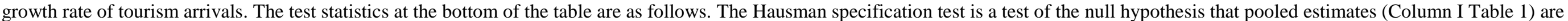

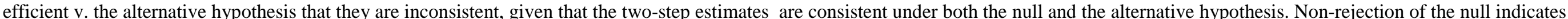

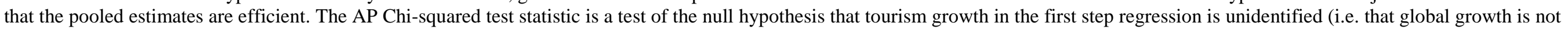

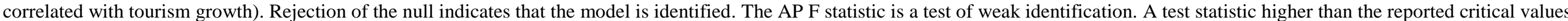

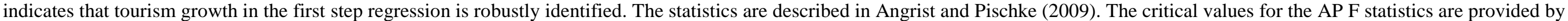
Stock and Yogo (2005). Additional diagnostics (similar to those reported at the bottom of Table 1) are available upon request. 


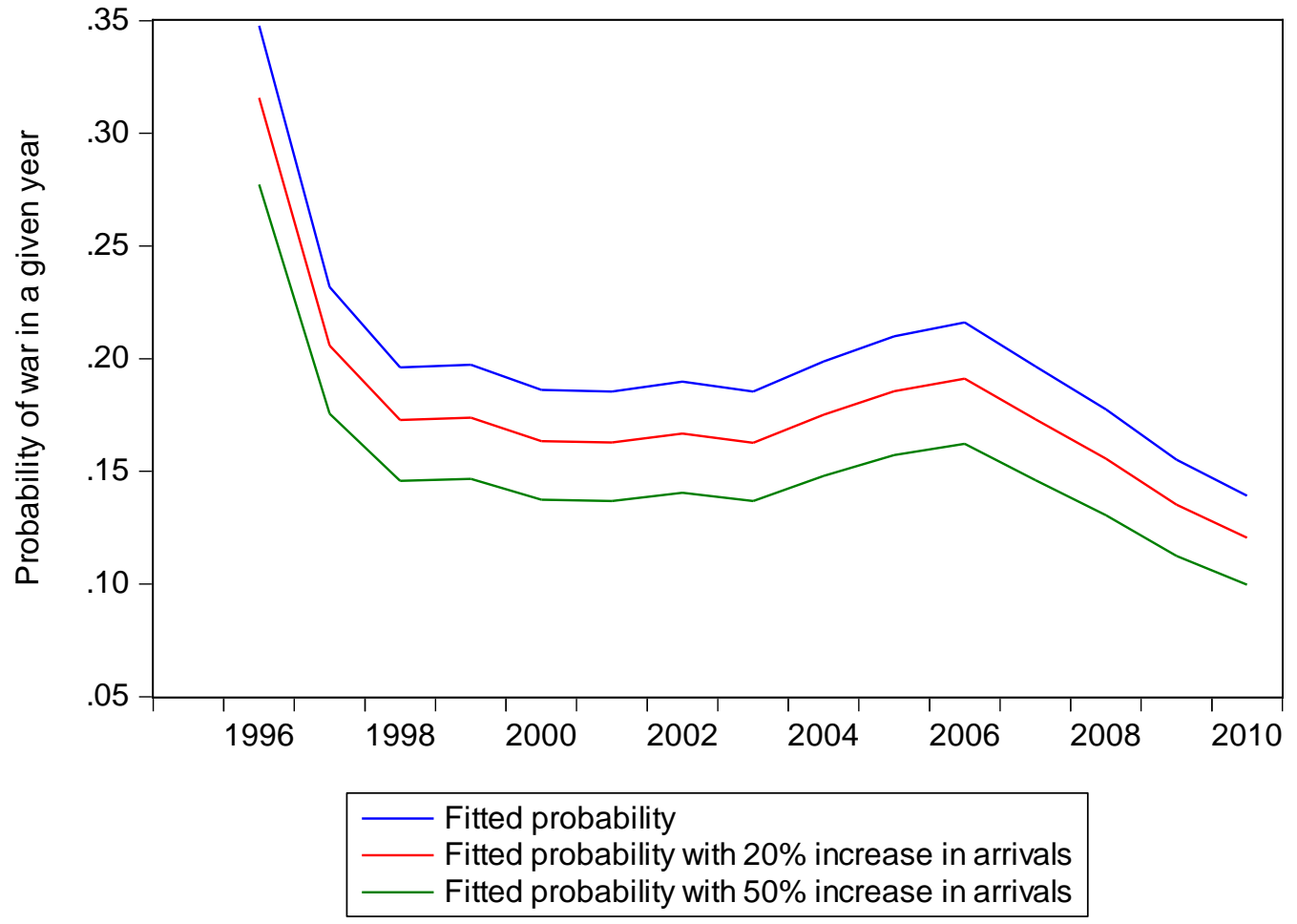

Figure 1. Probability of war and tourism in Russia, 1996-2010. 


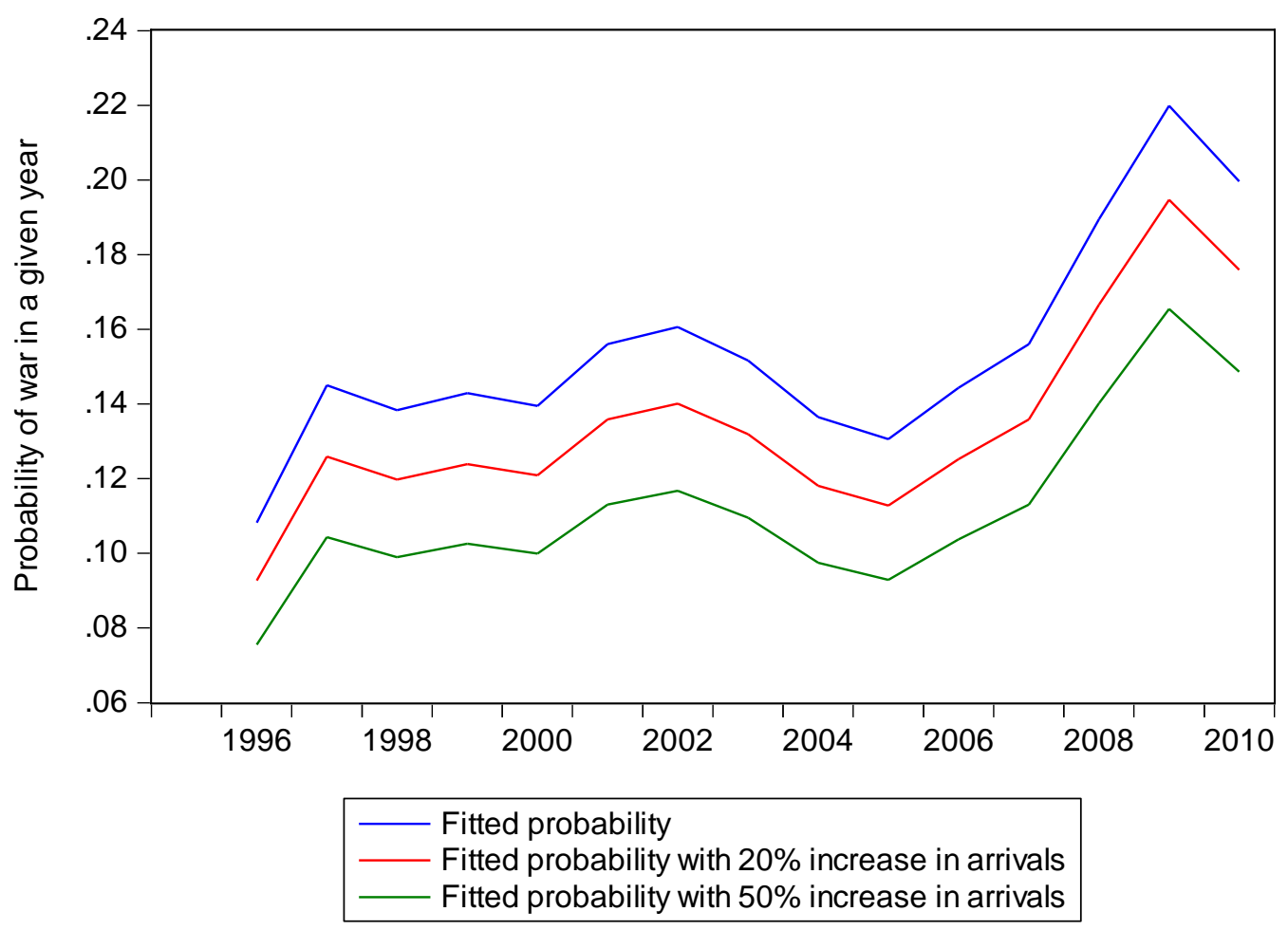

Figure 2. Probability of war and tourism in Sri Lanka, 1996-2010. 